\title{
Factors that Influence Rabies Dog Vaccination Among Dogs' Owner in Sukabumi District, West Java
}

\author{
Ardilasunu Wicaksono \\ Division of Veterinary Public Health \\ and Epidemiology, Department of \\ Animal Infectious Disease and \\ Veterinary Public Health \\ Faculty of Veterinary Medicine, IPB \\ University (Bogor Agricultural \\ University) \\ Bogor, Indonesia \\ vetsunuedu@gmail.com \\ Denny Widaya Lukman \\ Division of Veterinary Public Health \\ and Epidemiology, Department of \\ Animal Infectious Disease and \\ Veterinary Public Health \\ Faculty of Veterinary Medicine, IPB \\ University (Bogor Agricultural \\ University) \\ Bogor, Indonesia \\ dennylukman@hotmail.com
}

\author{
Abdul Zahid \\ Division of Veterinary Public Health \\ and Epidemiology, Department of \\ Animal Infectious Disease and \\ Veterinary Public Health \\ Faculty of Veterinary Medicine, IPB \\ University (Bogor Agricultural \\ University) \\ Bogor, Indonesia \\ abdulzahid_ilyas@yahoo.com \\ Yusuf Ridwan \\ Division of Parasitology and Medical \\ Entomology, Department of Animal \\ Infectious Disease and Veterinary \\ Public Health \\ Faculty of Veterinary Medicine, IPB \\ University (Bogor Agricultural \\ University) \\ Bogor, Indonesia \\ yridwan67@gmail.com
}

\author{
Etih Sudarnika \\ Division of Veterinary Public Health \\ and Epidemiology, Department of \\ Animal Infectious Disease and \\ Veterinary Public Health \\ Faculty of Veterinary Medicine, IPB \\ University (Bogor Agricultural \\ University) \\ Bogor, Indonesia \\ etih.sudarnika@gmail.com
}

\begin{abstract}
Sukabumi District located in West Java Province has not been free from rabies diseases. Thus, rabies should be taken seriously through several control programs. One of the programme were rabies mass vaccination targeting $80 \%$ vaccination coverage, however, there is many dog's owners did not want their dog being vaccinated. This study aimed to determine and to analyze the influence factors on dog vaccination program amongst dog's owner in Sukabumi District. A total of 141 dogs' owner was selected as respondents. Data were collected using structured questionnaires by interviewing the respondents. The ChiSquare Test and Gamma Correlation Test were used to determine the influence factors on dog vaccination practice. The result showed that there were three significant factors which influence the dog vaccination : 1$)$ the income level $\left(\chi^{2}=\right.$ 41.725, $\mathbf{p}=0.000), 2)$ the experience of dog's ownership $\left(\chi^{2}=\right.$ 15.485, $\mathrm{p}=0.006)$, and 3$)$ the knowledge about rabies $\left(\chi^{2}=\right.$ 15.712, $\mathrm{p}=0.006)$. The income level $(\mathrm{r}=0.503)$ and the knowledge about rabies $(r=0.469)$ were two factors that influence most with a strong and positive correlation. Based on our results, we can find the solution to alter the attitude and practice of dog's owner on dog vaccination program. Two influence factors could be improved to increase the participation of dog's owner to follow the rabies vaccination program.
\end{abstract} factors

Keywords-rabies, vaccination, dog's owner, influence

\section{INTRODUCTION}

Rabies is endemic in Indonesia whereas 24 of the 34 provinces have this serious problem. West Java is a province in Indonesia which are reportedly not free from rabies and plan to be declared free from rabies. Some districts in West Java are a dog supplier for several areas in Jakarta Province, Central Java Province and West Sumatra Province, and one of the districts is Sukabumi District. This district has not been free from rabies because they still have reported cases of rabies in animals and there are rabies positive cases [1]. Thus, rabies should be taken seriously through several control programs. One of the programme were mass vaccination targeting $80 \%$ coverage of the dog population for the success of the rabies eradication. Over $90 \%$ of human deaths from rabies worldwide are caused by dog bites. Mass vaccination, along with the effective control of dog populations, has been used successfully in many countries to control this disease. A lower success rate in developing countries is due to a number of factors, including vaccination campaigns that do not cover a sufficient number of animals or reach all communities [2]. However, the constraints are not all dog owners want their dog being vaccinated. This makes the rabies control programs becomes more difficult. Majority of dog owners are wild boar hunters and using their dogs for hunting and so many reasons given for refusing the dog vaccination program [1]. Therefore, this research was aimed to determine and to analyze the influence factors on dog vaccination program among dog's owner in Sukabumi District.

\section{MATERIALS AND METHODS}

\section{A. Respondents}

A total of 141 dog's owner was selected as respondents. Respondents were drawn from two sub-districts in Sukabumi District as many as 66 people from Jampang Tengah sub-district and 75 people from Cisolok sub-district. 


\section{B. Data Collection}

Data was collected using structured questionnaires by interviewing the respondents. The component on the questionnaires consisted of the respondents' characteristics and rabies vaccination practice. Pre-test and validity test of questionnaires were done before the questionnaires were used on the field in order to determine the suitability of the questionnaires.

\section{Data Analysis}

The design used for this study was the quantitative research design. The data was analyzed using descriptive statistics and nonparametric test. The Chi-Square Test and Gamma Correlation Test were used to determine the influence factors on dog vaccination practice.

\section{RESULTS AND DISCUSSION}

\section{A. Dog's Owner Characteristics}

The result showed that majority of respondents $(75.8 \%)$ had low educational level and most of them (56.7\%) hadn't been exposed from the information about rabies. 59.6\% respondent worked as farmer/hodge with low income level below one million rupiah $(69.5 \%)$. Their experience on raising the dogs mostly (53.2\%) under 3 years and they kept the dogs for boar hunting purposes $(62.4 \%)$. Moreover, majority of them $(82.3 \%)$ never vaccinate the dogs especially for rabies vaccination and $22.7 \%$ of respondents had poor knowledge about rabies. The information about respondent characteristics showed in Table 1.

TABLE I. CHARACTERISTICS OF DOG'S OWNER IN SUKABUMI DISTRICT

\begin{tabular}{|l|c|c|}
\hline \multicolumn{1}{|c|}{ Respondent characteristics } & $\mathrm{n}$ & $\%$ \\
\hline Low educational level & 15 & 10.6 \\
- No school & 92 & 65.2 \\
\hline Elementary school & 84 & 59.6 \\
\hline $\begin{array}{l}\text { Low income level (<1 million } \\
\text { rupiah / month) }\end{array}$ & 98 & 69.5 \\
\hline $\begin{array}{l}\text { Low experience of dog's ownership } \\
\text { (<3 years) }\end{array}$ & 75 & 53.2 \\
\hline Never got information about rabies & 80 & 56.7 \\
\hline Keeping dogs for boar hunting & 88 & 62.4 \\
\hline Never vaccinate the dogs & 116 & 82.3 \\
\hline Poor knowledge about rabies & 32 & 22.7 \\
\hline
\end{tabular}

\section{B. The Influenced Factors on Dog Vaccination}

The study found out that there was a significant relationship between the respondent characteristics to the dog vaccination practice. The variables which were determine as possible influence factors are educational level, income level, rabies information access, experience of dog's ownership, and knowledge about rabies. The influenced factors on dog vaccination practice showed in Table. 2.
TABLE II. THE INFLUENCED FACTORS ON DOG VACCINATION

\begin{tabular}{|l|c|c|}
\hline \multicolumn{2}{c}{ PRACTICE } \\
\hline Education level & $\chi^{2}$ & p value \\
\hline Income level & 1.107 & 0.919 \\
\hline Rabies information access & 41.725 & $0.000 *$ \\
\hline Experience of dog's ownership & 2.177 & 0.140 \\
\hline Knowledge about rabies & 15.485 & $0.006 *$ \\
\hline *Significant at p $<0.05$ & 15.712 & $0.006^{*}$ \\
\hline
\end{tabular}

The result showed that there were three significant factors which influence the dog vaccination those were the income level $\left(\chi^{2}=41.725, \mathrm{p}=0.000\right)$, the experience of dog's ownership $\left(\chi^{2}=15.485, \mathrm{p}=0.006\right)$, and the knowledge about rabies $\left(\chi^{2}=15.712, \mathrm{p}=0.006\right)$. On those three factors, there were only two factors that influence most with a strong and positive correlation those were the income level $(\mathrm{r}=0.503)$ and the knowledge about rabies $(\mathrm{r}=0.469)$. Education is an important factor for people to increase their knowledge and awareness about vaccination [3]. Moreover, the acceleration of people's knowledge in the community can support the success of the disease control program $[4,5]$. However, the level of knowledge can be increase by facilitate the rabies information access on peoples [6].

\section{CONCLUSION}

From this study, we can find the solution to alter the attitude and practice of dog's owner on dog vaccination program. Two influence factors could be improved to increase the participation of dog's owner to follow the rabies vaccination program. The level of income can be increased with the enhancement of the economic conditions but of course it would take a long time. Another influence factor that is easily improved is the level of knowledge of dog's owner, for example through extension and advisory services related to the risk of rabies and the importance of dog vaccination for rabies control program.

\section{ACKNOWLEDGMENT}

The authors would like to express the deepest sense of gratitude to the Ministry of Research, Technology, and Higher Education for the funding of this research with the scheme of Institutional Research. The authors are grateful to Dinas Peternakan Kabupaten Sukabumi and the students (research assistant) for the support on this research.

\section{REFERENCES}

[1] A Wicaksono, AZ Ilyas, E Sudarnika, DW Lukman, Y Ridwan, Knowledge, Attitude, and Practice Study of Dog Owners Related to Rabies In Sukabumi Distric, West Java. Jurnal Veteriner 19(2):230 241 (2018)

[2] NA Ceballos, D Karunaratna, AA Setien, Control of Canine Rabies in Developing Countries: Key Features and Animal Welfare Implications. Rev. sci. tech. Off. int. Epiz 33(1), 311-321 (2014).

[3] J Regmi, "Socio-cultural Influences on Vaccination-Vaccinators Perspective, Study from Nepal," MSc. thesis, University of Eastern Finland, 2014 
[4] A Wicaksono, M Sudarwanto, Increasing of Milk Quality in Small Scale Dairy Farms in Boyolali through Extension and Advisory for Dairy Farmers. Jurnal Agrokreatif 2(2), 55-60 (2016).

[5] A Wicaksono, E Sudarnika, C Basri. Biosecurity Condition on Bird Vendors Related to Avian Influenza in Jakarta. Jurnal Sain Veteriner 35(2), 269-276 (2017).
6] T Guadu, A Shite, M Chanie, B Bogale, T Fentahun, Assessment of Knowledge, Attitude and Practices about Rabies and Associated Factors: In the Case of Bahir Dar Town. Global Veterinaria 13(3):348-354 (2014) 